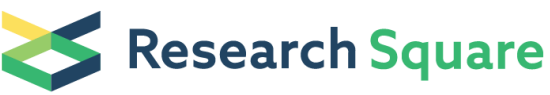 \\ Preprints are preliminary reports that have not undergone peer review. \\ They should not be considered conclusive, used to inform clinical practice, \\ or referenced by the media as validated information.
}

\section{A Case Report of Multifocal PEComa Affecting the Pancreas and Liver and a Literature Review}

\author{
Jian Guan \\ Cancer Hospital Chinese Academy of Medical Sciences https://orcid.org/0000-0001-9194-3167 \\ Guihua Shen \\ Chinese Academy of Medical Sciences Cancer Institute and Hospital: Cancer Hospital Chinese Academy of Medical Sciences \\ Wenting Huang ( $\square$ huangwt@cicams.ac.cn ) \\ Pathology of Department, National Cancer Center/National Clinical Research Center for Cancer/Cancer Hospital, Chinese Academy of Medical \\ Sciences and Peking Union Medical College, Beijing, 100021, China
}

\section{Case Report}

Keywords: case report, perivascular epithelioid cell tumor (PEComa), multifocal

Posted Date: June 14th, 2021

DOI: https://doi.org/10.21203/rs.3.rs-606941/v1

License: (c) (i) This work is licensed under a Creative Commons Attribution 4.0 International License. Read Full License 


\section{Abstract}

Background: Perivascular epithelioid cell tumor (PEComa) is a rare tumor derived from soft tissues and organs. Its morphology includes several types such as angiomyolipoma, lymphangiomyomatosis and pulmonary clear-cell "sugar" tumor with similar immunophenotype. Multifocal PEComa is a rarer lesion, which would cause confusion in imaging examination and clinical management. We reported a case of multifocal angiomyolipoma in pancreas and liver. At the same time, we reviewed the literature to explore the clinicopathological characteristics and possible pathogenesis of multifocal PEComa.

Case presentation: A 28-year-old woman presented with a lesion in the head of the pancreas and liver $5 / 6$ segment respectively, initially suspected of pancreatic tumor with liver metastasis. In the liver mass resection and pancreatic mass biopsy, it was found that the two lesions had similar pathological morphology. The tumor cells were mainly epithelioid and spindle cells arranged in nests pattern and partially radially distributed around blood vessels. The tumors had no malignant manifestations in morphology. Immunohistochemical assay showed that the tumor cells expressed melanocytic and smooth muscle markers. A diagnosis of pancreatic and liver angiomyolipoma was rendered.

Conclusion: Based on the case we reported here and the other 12 cases we reviewed for the study, multifocal PEComa with no indications of malignancy based on morphology is biologically benign and has a good prognosis. The lesion may be caused by the blood dissemination of tumor cells rather than metastasis. Radical treatment should not be used in clinical management. In addition, follow-up for PEComa would be long-term, because a second PEComa lesion may appear many years later for the "benign" dissemination of tumor cells.

\section{Background}

Perivascular epithelioid cell neoplasms (PEComa) are a type of tumors originating in soft tissues and organs. The tumor cells exhibit an association with the vascular wall and typically express melanocytic and smooth muscle markers. Regarding pathological morphology, PEComa is classified as angiomyolipoma (AML), lymphangiomyomatosis (LAM), pulmonary clear cell sugar tumor (CCST) or other tumor types with perivascular epithelioid cell differentiation (PEComa-not otherwise specified, PEComa-NOS), and these classifications are characterized by similar immunohistochemical presentations[1].

In some rare cases, multiorgan and multifocal PEComa will occur. The most common type is angiomyolipoma. It is not easy to distinguish some angiomyolipoma that contain less fat from other solid tumors according to imaging examination. In addition, due to multifocal occurrence, PEComa mimics metastatic tumors, making diagnosis and treatment decisions difficult.

Here, we report a case of simultaneous angiomyolipoma in the liver and pancreas of a young patient. The case initially was suspected to be a pancreatic tumor with liver metastasis, causing confusion in clinical diagnosis.

\section{Case Report}

A 28-year-old woman was referred to our hospital for a lesion on the head of the pancreas that was found in a physical examination. She had no obvious clinical symptoms and no personal or family history of other diseases. Abdominal contrast-enhanced computed tomography (CE-CT) demonstrated a 1.9-cm-sized low-density lesion at the pancreatic head, which was obviously enhanced in the arterial phase and decreased during the portal and delayed phases (Figure 1). The lesion had an irregular shape but was not related to the pancreatic duct system. Additionally, a low-density lesion was located in the segment $5 / 6$ junction area of the liver that was $1.1 \times 1.0 \mathrm{~cm}$ in size (Figure 2 ). No enlarged lymph nodes were noted in the abdominal pelvic cavity or groin. Based on these findings, possible diagnoses, such as solid pseudopapillary tumor or neuroendocrine tumor of pancreas, were considered. The nodule at the junction of liver S5/6 was suspected to be a metastasis from the pancreatic lesion.

It was difficult to further confirm the diagnosis before surgery, so the patient underwent an operation involving "fluorescence laparoscopic liver tumor resection + pancreatic tumor biopsy" to explore the tumor. In the intraoperative frozen tissue pathological examination, a well-defined $1.2 \times 0.8$ $\mathrm{cm}$ solitary nodule was noted in the liver segmental resection. The cut surface of the tumor was gray-yellow and soft, and the boundary was relatively clear. The remainder of the liver appeared noncirrhotic. Microscopic examination showed that the tumor cells were epithelioid or spindleshaped and arranged in a nested pattern. The cytoplasm of the tumor cells was transparent and eosinophilic. No necrosis and mitotic figures were observed. Therefore, the intraoperative pathological diagnosis was an epithelioid tumor that was considered a PEComa. Furthermore, pancreatic puncture biopsy was performed; the pancreatic tumor had morphology similar to that of the hepatic tumor. Although the intraoperative frozen section did not show clear indications of malignancy, metastatic lesions could not be excluded. Therefore, it was recommended to suspend the pancreatic surgery and wait for the postoperative pathological diagnosis to decide the next steps of management.

The morphology of the paraffin-embedded tissue showed a small amount of fat cells and obvious thin-walled sinusoidal vascular structures in the tumor of liver (Figure 3A, 3B). The tumor cells were epithelioid or spindle-shaped. Epithelioid cells had obvious nucleoli and central concentrated cytoplasm, which were distributed in the perivascular region in a radial pattern (Figure 3C). Some foci displayed more "myoid" spindle cells arranged in whorled and interlacing fascicles. Additionally, in postoperative specimens, no necrosis or mitotic figures were noted. The same features were noted for the pancreatic tumor (Figure 4A). Immunohistochemical assay showed that tumor cells in the liver were positive for HMB-45, Melan-A, 
SMA and S-100 (Figure 3D, 3E, 3F), but negative for AE1/AE3, CK18, CK7, CK20, Hepatocytes, Arg-1 and GPC3. Ki-67 staining revealed a low proliferation index $(5 \%+)$. The tumor cells in the pancreas were positive for HMB45 (because the tumor component was small,

no additional immunohistochemical assay was performed in pancreatic tumors). Therefore, both liver and pancreatic tumors were diagnosed as angiomyolipoma with epithelioid pattern. Half a month later, the patient underwent "laparoscopic resection of pancreatic tumor + release of intestinal adhesions". A $2 \times 2 \times 1.5 \mathrm{~cm}$ solid mass was located in the pancreatic body and neck, which was soft, grayish yellow with clear borders. The histomorphology was similar to the hepatic tumor with the exception of more adipose component (Figure 4B, 4C). No cell pleomorphism, necrosis or mitotic figures, vascular tumor thrombus or nerve invasion were observed. The border of the tumor was not infiltrative. Its immunophenotype was the same as that of the liver tumor, and Ki-67 staining also revealed a low proliferation index (2\%+) (Figure 4D, 4E, 4F). According to the criteria for malignancy of PEComa described by Folpe et al. [2], there was no malignant indication in two lesions. We suggested that the tumors were multifocal epithelioid angiomyolipoma originating from the liver and pancreas rather than tumors with distant metastasis.

Considering that the patient was young and had multiple PEComa lesions, a thorough examination of the patient was performed. No other clinical symptoms related to tuberous sclerosis complex were found. Next-generation sequencing (NGS) showed no TSC1/TSC2 germline mutations. After the surgical operation, the patient did not receive any adjuvant therapy. After 22 months of follow-up, she was in good condition, and no recurrence or metastasis was found.

\section{Discussion}

Multifocal PEComa and tuberous sclerosis complex

PEComa is a rare tumor type, and multifocal PEComa is even rarer. Some cases of multifocal PEComa are associated with tuberous sclerosis complex (TSC), which is due to germline mutations of the TSC1 (9q3.4) and TSC2 (16p13.3) genes[2]. PEComa related to TSC often occurs in young patients with bilateral or multifocal origin and a fast growth rate. According to the clinical diagnostic criteria of TSC proposed by the 2012 International Tuberous Sclerosis Complex Consensus Conference[3], there are 11 major features and 6 minor features included in the clinical diagnostic criteria of TSC. Cases with 2 major features or 1 major feature with ${ }^{3} 2$ minor features meet the diagnostic criteria of clinically confirmed TSC. The occurrence of ${ }^{3} 2$ angiomyolipoma or lymphangiomyomatosis is one of the major features, respectively. However, if there only the two manifestations are noted in the clinic, the patient cannot be diagnosed as clinically confirmed TSC. Cases with either 1 major feature or ${ }^{3} 2$ minor features meet the clinical diagnostic criteria for presumptive TSC. Therefore, multifocal PEComa cases, especially those with multifocal angiomyolipoma or lymphangiomyomatosis, are at least clinically presumptive TSCs. For such cases, it is best to perform genetic testing to assist in the diagnosis of TSC. Here we reviewed the English literature from 2000 to 2020 and collected a total of 12 cases of multifocal PEComa, not including cases of malignant PEComa with metastasis to other organs (Table 1). Among the 12 collected cases, 2 cases were reported as clinically definite TSC (case \#4 [4]and \#6[5]). The two cases were both bilateral renal angiomyolipoma and multiple lymphangiomyomatosis in the lung. Two other cases 『case \#1 [6]and \#9[7]『showed no mutations in the TSC1/2 gene based on genetic analysis, and no other TSC-related clinical manifestations were mentioned in the report, indicating that multifocal PEComa is not always related to TSC. PEComa unrelated to germline mutations in the TSC1/2 gene are sporadic cases. Some of these cases also have somatic mutations in the TSC1/2 gene[8], and some have other genetic changes[9].

\section{Morphology type of PEComa in multifocal cases}

In multifocal PEComa cases, the most common types are angiomyolipoma and lymphangiomyomatosis (mostly multifocal, small lesions less than $1 \mathrm{~cm}$ in diameter), which is consistent with solitary PEComa. Angiomyolipoma is composed of three components with different proportions: mature adipose tissue, which is the main clue for imaging diagnosis of PEComa; thick-walled, twisted blood vessels of various sizes that are often accompanied by hyalinosis; and irregular sheet-like or intersecting smooth muscle-like bundles. Epithelioid or spindle-like cells can be observed around blood vessels. The epithelioid-like cells are rich in eosinophilic granules or hyaline cytoplasm, and the nucleus is round with small nucleoli. A kind of specific cell morphology is noted: tumor cells with eosinophilic central cytoplasm and transparent surrounding cytoplasm, which is the socalled "spider's web cell". If the tumor is mainly composed of such epithelioid cells, it should be diagnosed as epithelioid angiomyolipoma. Some studies report that pure epithelioid PEComa has malignant potential, and is often related to younger patients, larger tumor sizes and disease progression[10, 11]. Among multifocal PEComa cases, one of the cases (case \#12[12]) had multiple epithelioid angiomyolipoma in the kidney and liver. This case seemed to have a faster second tumor occurrence rate (9-month interval). In immunohistochemistry analyses, epithelioid cells mostly express HMB45 and express MelanA and MiTF to various degrees. Spindle cells express SMA more often, desmin occasionally and typically no S-100 nuclear staining. Lymphangiomyomatosis is a lesion with multiple cysts that occurs in the lungs and is composed of lymphatic vessels with proliferating lymphatic myocytes around them. Early lesions are distributed in small clusters on the edge of the cyst or along blood vessels, lymphatic vessels and bronchioles. There are two forms of tumor cells: small spindle cells or oval cells and epithelioid cells with a larger volume and rich cytoplasm. Small spindle cells or oval cells express SMA, and desmin occasionally, whereas epithelial-like cells express HMB45 and Melan-A. Although the organization of angiomyolipoma and lymphangiomyomatosis are quite different, the tumor cells that comprise these tumors exhibit 
similar morphology and immunophenotype. Therefore, some researchers believe that lymphangiomyomatosis is derived from a "benign" metastasis of other PEComa (such as angiomyolipoma) tumor cells[13].

\section{Diagnostic criteria for benign and malignant PEComa}

Most PEComa are benign tumors; some cases exhibit malignant biological behaviors and even distant metastasis. However, given the rarity of this tumor, there is still a lack of uniformly accepted morphological criteria to predict prognosis. Folpe et al [14] explained the criteria of malignancy in PEComa from soft tissue and gynecologic origin: large tumor with diameter greater than $5 \mathrm{~cm}$, invasive growth pattern, obvious nuclear atypia, necrosis, mitotic figures more than 1/50 HPF and vascular nerve invasion are related with aggressive clinical behavior. Other morphological features, such as the presence of epithelioid components, are also considered to be related to poor biological behavior[11]. It is recommended to perform more resection in the specimen to observe any indicators of malignancy. However, in the 35 cases of gastrointestinal PEComa summarized by Doyle[15], through multifactor analysis, some malignant signs, such as $\geq 2 / 10$ HPF mitotic figures, diffuse pleomorphism, marked nuclear atypia, large tumor size and necrosis, were not significantly related to distant metastasis.

\section{Multifocal lesions or metastases}

Since the criteria for suggesting malignancy through morphology are not very clear, Some authors suppose that the basis for the occurrence of multifocal PEComa is metastasis[16], considering all PEComa have malignant potential. Whereas some authors believe that the formation of multifocal PEComa is the result of a multicentric occurrence given the low growth and good prognosis[17].

We found some clinicopathological characteristics of multifocal PEComa in the cases collected in this article. Firstly, although PEComa exhibit a wide anatomical distribution, the most prevalent locations are blood-rich organs, such as the kidneys, lungs and liver. In multifocal PEComa, we found that the lung is the most involved organ (10 out of 12 collected cases). And in almost all metachronous cases (7 out of 8 metachronous cases), the later onset tumor is always pulmonary PEComa (LAM or AML). The next common organs are liver and kidney. And there was another case of PEComa involving the spleen, which is also a blood-rich organ, although very rare. Organs with abundant blood supply are conducive to the dissemination of tumor cells. Secondly, multifocal PEComa can involve two or more organs or locations, and most cases (11 out of 12 cases) have multifocal lesions within one organ. The lung was the most common organ with multifocal lesions, also followed by the liver and kidney. The growth pattern of multiple foci in an organ is also similar to that of metastatic tumors. Additionally, angiomyolipoma, lymphangiomyomatosis, or other types of PEComa are rich in vascular lymphatic vessels and exhibit the characteristics of perivascular growth pattern. It is prone to the spread of tumor cells through the vasculature.

However, these multifocal PEComa cases have a chronic clinical course. In the collected 8 cases of metachronous multifocal PEComa, except for 2 cases in which the second tumor occurred within one year (Case \#4[4]: After bilateral nephrectomy for AML, LAM occurred in both lungs after 2 months of hemodialysis; Case\#12[12]:, hepatic multiple epithelial PEComa appeared 9 months after renal epithelial PEComa was found), the second tumor in the remaining 6 cases was found to be ranged from 5 to 26 years later, with an average of 12.5 years. Moreover, among the cases with documented prognosis, most multifocal PEComa lesions remained stable, with no recurrence or metastasis occurred during the follow-up. One case was even followed up for 12 years[18]. This clinical course is more like a benign, multicentric disease, rather than a malignant, metastatic disease.

Therefore, from the two seemingly contradictory biological behaviors described above, we hypothesize the pathogenesis of some sporadic multifocal PEComa cases involves tumor cells spread by the blood, which may be due to the operation performed for the first tumor or the close relationship with the blood vessel wall. During a long dissemination process, migrating cells encounter blood-rich organs, forming multiple tumors with similar cell morphology and immunophenotype. So, the occurrence of multifocal PEComa is the result of distant migration of "angiotropic" tumor cells, which is a type of "benign" metastasis. However, this hypothesis that is inferred from the clinicopathological characteristics of multifocal PEComa must be supported by further molecular biology research.

In summary, multifocal PEComa, excluding metastatic cases of malignant PEComa, is benign or indolent tumors. The genesis of such tumor may be related to the blood dissemination of tumor cells that ultimately encounter distant organs. It is a benign dissemination process rather than metastasis. Therefore, radical treatment should not be performed for such tumors in the clinical management. However, for large tumor, because of rich in blood supply, it requires early treatment for risk of bleeding and other symptoms. In addition, even cases of PEComa with benign pathological morphology should be monitored for a long time, because a second or a greater number of PEComa lesions may appear many years later.

\section{Abbreviations}

PEComa: Perivascular epithelioid cell neoplasm; AML: angiomyolipoma; LAM: lymphangiomyomatosis; CCST: clear cell sugar tumor; PEComa-NOS: PEComa-not otherwise specified; CE-CT: contrast-enhanced computed tomography; TSC: tuberous sclerosis complex; NGS: next-generation sequencing; M: metachronous; S: simultaneous

\section{Declarations}




\section{Ethics approval and consent to participate:}

Written informed consent was obtained from the patient for publication of this case report and accompanying images. A copy of the written consent is available for review by the Editor in-Chief of this journal.

\section{Consent for publication:}

Written informed consent for publication was obtained from the patient.

\section{Availability of data and materials:}

All data generated or analysed during this study are included in this published article.

\section{Competing interests:}

The authors declare that they have no competing interests.

\section{Funding:}

Supported by Sanming Project of Medicine in Shenzhen『No.SZSM201812076『

\section{Authors' contributions:}

All authors contributed in the writing of the manuscript and read and approved the final manuscript.

\section{Acknowledgements:}

Not applicable.

\section{References}

1. Thway, K. and C. Fisher, PEComa: morphology and genetics of a complex tumor family. Ann Diagn Pathol, 2015. 19(5): p. 359-68.

2. Henske, E.P., et al., Tuberous sclerosis complex. Nat Rev Dis Primers, 2016. 2: p. 16035.

3. Northrup, H. and D.A. Krueger, Tuberous sclerosis complex diagnostic criteria update: recommendations of the 2012 linternational Tuberous Sclerosis Complex Consensus Conference. Pediatr Neurol, 2013. 49(4): p. 243-54.

4. Nasir, K. and A. Ahmad, Giant renal angiomyolipomas and pulmonary lymphangiomyomatosis. Saudi J Kidney Dis Transpl, 2010. 21(2): p. 314-9.

5. Chang, M.H. and H. Yao-Peng, Lymphangioleiomyomatosis, multifocal micronodular pneumocyte hyperplasia, and clear-cell micronodules in a 39-year-old woman with tuberous sclerosis: a case report. Int J Surg Pathol, 2010. 18(6): p. 522-5.

6. Sun, X., et al., Coexistence of pulmonary lymphangioleiomyomatosis and pulmonary angiomyolipoma. BMC Pulm Med, 2016. 16(1): p. 120.

7. Saito, M., et al., Multifocal angiomyolipoma affecting the liver and lung without tuberous sclerosis. J Clin Pathol, 2004. 57(2): p. 221-4.

8. Dabora, et al., Mutational Analysis in a Cohort of 224 Tuberous Sclerosis Patients Indicates Increased Severity of TSC2, Compared with TSC1, Disease in Multiple Organs. American Journal of Human Genetics, 2001.

9. Vannucchi, M., et al., TFE3 Gene Rearrangement in Perivascular Epithelioid Cell Neoplasm (PEComa) of the Genitourinary Tract. Clinical Genitourinary Cancer, 2020.

10. Lee, W., Does epithelioid angiomyolipoma have poorer prognosis, compared with classic angiomyolipoma? Investigative \& Clinical Urology, 2018.

11. Nese, N., et al., Pure Epithelioid PEComas (So-Called Epithelioid Angiomyolipoma) of the Kidney. American Journal of Surgical Pathology, 2011. 35(2): p. 161-176.

12. Mai, K.T., et al., Fine needle aspiration biopsy of epithelioid angiomyolipoma. A case report. Acta Cytol, 2001. 45(2): p. 233-6.

13. Henske, E.P., Metastasis of benign tumor cells in tuberous sclerosis complex. Genes Chromosomes Cancer, 2003. 38(4): p. 376-81. 
15. Doyle, L.A., J.L. Hornick, and C.D. Fletcher, PEComa of the gastrointestinal tract: clinicopathologic study of 35 cases with evaluation of prognostic parameters. Am J Surg Pathol, 2013. 37(12): p. 1769-82.

16. Dimmler, A., et al., Late pulmonary metastasis in uterine PEComa. J Clin Pathol, 2003. 56(8): p. 627-8.

17. Fadare, O., et al., Perivascular epithelioid cell tumor (PEComa) of the uterine cervix associated with intraabdominal "PEComatosis": A clinicopathological study with comparative genomic hybridization analysis. World J Surg Oncol, 2004. 2: p. 35.

18. Kasuno, K., et al., Pulmonary angiomyolipoma recurring 26 years after nephrectomy for angiomyolipoma: benign clinical course. Clin Nephrol, 2004. 62(6): p. 469-72.

19. Neri, S., et al., Multiple perivascular epithelioid cell tumors: clear cell tumor of the lung accompanied by angiomyolipoma of the liver. Ann Thorac Cardiovasc Surg, 2014. 20 Suppl: p. 453-6.

20. Bhardwaj, N., G. Garcea, and D. Lloyd, A rare case of multi-focal angiomyolipoma affecting the pancreas and liver. J Surg Case Rep, 2012. 2012(4): p. 5.

21. Hino, H., et al., Angiomyolipoma in the lung detected 15 years after a nephrectomy for renal angiomyolipoma. Ann Thorac Surg, 2010. 89(1): p. 298-300.

22. Gleeson, F.C., et al., The differential broadens. EUS FNA appearance and cytological findings of pancreatic angiomyolipoma. Jop, 2008. 9(1): p. $67-70$.

23. Kim, N.R., et al., Pulmonary lymphangioleiomyomatosis and multiple hepatic angiomyolipomas in a man. Pathol Int, 2003. 53(4): p. 231-5.

\section{Tables}

Table 1 List of multifocal PEComa cases 


\begin{tabular}{|c|c|c|c|c|c|c|c|c|c|c|}
\hline NO. & Ref. & Sex & Age & TSC & $\begin{array}{l}\text { Onset } \\
\text { interval }\end{array}$ & $\begin{array}{l}1^{\text {st }} \text { PEComa } \\
\text { (Max } \\
\text { diameter) } \\
\text { (Time of } \\
\text { occurrence) }\end{array}$ & $\begin{array}{l}2^{\text {nd }} \text { PEComa } \\
\text { (Max } \\
\text { diameter) } \\
\text { (Time of } \\
\text { occurrence) }\end{array}$ & $\begin{array}{l}\text { Pathological } \\
\text { description }\end{array}$ & $\begin{array}{l}\text { Clinical } \\
\text { management }\end{array}$ & Prognosis \\
\hline 1 & $\begin{array}{l}\text { Sun, X. } \\
(2016)[6] .\end{array}$ & $\mathrm{F}$ & 38 & $\begin{array}{l}\text { No (gene } \\
\text { assay } \\
\text { verified) }\end{array}$ & M & $\begin{array}{l}\text { Right renal: } \\
\text { AML ( } 17 \text { years } \\
\text { before) }\end{array}$ & $\begin{array}{l}\text { Bilateral lung: } \\
\text { multiple LAM } \\
\text { AML; Left } \\
\text { renal: AML }\end{array}$ & No mention & $\begin{array}{l}\text { mTOR } \\
\text { inhibitor: } \\
\text { sirolimus } \\
\text { therapy }\end{array}$ & $\begin{array}{l}\text { the renal } \\
\text { and } \\
\text { pulmonary } \\
\text { AML } \\
\text { shrank, but } \\
\text { pulmonary } \\
\text { LAMs were } \\
\text { unchanged }\end{array}$ \\
\hline 2 & $\begin{array}{l}\text { Neri, S. } \\
(2014) \\
\text { [19]. }\end{array}$ & M & 38 & No mention & M & $\begin{array}{l}\text { Liver: } \\
\text { AML }(7.5 \mathrm{~cm})(5 \\
\text { years before })\end{array}$ & $\begin{array}{l}\text { Right lung: } \\
\text { AML(1.8cm) }\end{array}$ & $\begin{array}{l}\text { No malignant } \\
\text { phenotype }\end{array}$ & $\begin{array}{l}\text { Surgical } \\
\text { resection }\end{array}$ & $\begin{array}{l}\text { no } \\
\text { recurrence }\end{array}$ \\
\hline 3 & $\begin{array}{l}\text { Bhardwaj, } \\
\text { N. }(2012) \\
{[20] .}\end{array}$ & M & 61 & No mention & S & $\begin{array}{l}\text { Pancreas: } \\
\text { solitary AML }\end{array}$ & $\begin{array}{l}\text { Liver: multiple } \\
\text { AML }\end{array}$ & No mention & $\begin{array}{l}\text { Surgical } \\
\text { resection }\end{array}$ & $\begin{array}{l}\text { intrahepatic } \\
\text { lesions } \\
\text { progressed }\end{array}$ \\
\hline 4 & $\begin{array}{l}\text { Nasir, K. } \\
\text { and A. } \\
\text { Ahmad } \\
(2010)[4]\end{array}$ & $\mathrm{F}$ & 48 & Yes & M & $\begin{array}{l}\text { Bilateral renal: } \\
\text { AML(right: } \\
\text { 16cm; left: } \\
22 \mathrm{~cm} \text { ) }\end{array}$ & $\begin{array}{l}\text { Bilateral } \\
\text { Lung: } \\
\text { LAM }(1.5 \mathrm{~cm}) \\
\text { (2 month } \\
\text { after } \\
\text { hemodialysis } \\
\text { for bilateral } \\
\text { nephrectomy } \\
\text { ) }\end{array}$ & $\begin{array}{l}\text { Renal AML: } \\
\text { pleomorphism } \\
\text { focally }\end{array}$ & $\begin{array}{l}\text { Bilateral } \\
\text { nephrectomy }\end{array}$ & $\begin{array}{l}\text { The } \\
\text { pulmonary } \\
\text { tumors } \\
\text { were stable }\end{array}$ \\
\hline 5 & $\begin{array}{l}\text { Hino, } \mathrm{H} . \\
(2010) \\
{[21]}\end{array}$ & $\mathrm{F}$ & 52 & No mention & M & $\begin{array}{l}\text { Renal: } \\
\text { AML(15 years } \\
\text { before) }\end{array}$ & $\begin{array}{l}\text { Lung: } \\
\text { multiple AML }\end{array}$ & $\begin{array}{l}\text { Pulmonary } \\
\text { AML: no } \\
\text { malignant } \\
\text { phenotype }\end{array}$ & $\begin{array}{l}\text { Surgical } \\
\text { resection }\end{array}$ & Stable \\
\hline 6 & $\begin{array}{l}\text { Chang, } \\
\text { M. H. and } \\
\text { H. Yao- } \\
\text { Peng } \\
\text { (2010)[5] }\end{array}$ & $\mathrm{F}$ & 39 & Yes & $S$ & $\begin{array}{l}\text { Bilateral renal } \\
: A M L\end{array}$ & $\begin{array}{l}\text { Lung: } \\
\text { LAM,MMPH, } \\
\text { and clear-cell } \\
\text { micronodules }\end{array}$ & $\begin{array}{l}\text { No malignant } \\
\text { phenotype }\end{array}$ & $\begin{array}{l}\text { Surgical } \\
\text { resection }\end{array}$ & No mention \\
\hline 7 & $\begin{array}{l}\text { Gleeson, } \\
\text { F. Cl. } \\
(2008) \\
{[22] .}\end{array}$ & $\mathrm{F}$ & 44 & No mention & S & $\begin{array}{l}\text { Right renal: } \\
\text { multiple AML } \\
\text { (From } 0.7 \mathrm{~cm} \\
4 \text { years ago to } \\
2.6 \mathrm{~cm} \\
\text { ) }\end{array}$ & $\begin{array}{l}\text { Pancreas: } \\
\text { Multiple } \\
\text { AML(0.6- } \\
1.2 \mathrm{~cm})\end{array}$ & $\begin{array}{l}\text { No malignant } \\
\text { phenotype }\end{array}$ & $\begin{array}{l}\text { Surgical } \\
\text { resection }\end{array}$ & No mention \\
\hline 8 & $\begin{array}{l}\text { Kasuno, } \\
\text { K., et al. } \\
(2004) \\
{[18] .}\end{array}$ & $\mathrm{F}$ & 57 & No mention & M & $\begin{array}{l}\text { Renal: } \\
\text { AML }(26 \text { years } \\
\text { before })\end{array}$ & $\begin{array}{l}\text { Bilateral lung: } \\
\text { multiple } \\
\text { AML(0.5- } \\
1.5 \mathrm{~cm}) ; \\
\text { Spleen: AML }\end{array}$ & $\begin{array}{l}\text { No malignant } \\
\text { phenotype }\end{array}$ & $\begin{array}{l}\text { Surgical } \\
\text { resection }\end{array}$ & $\begin{array}{l}\text { No } \\
\text { recurrence } \\
\text { (followed } \\
\text { up for } 12 \\
\text { years) }\end{array}$ \\
\hline 9 & $\begin{array}{l}\text { Saito, M. } \\
(2004)[7] .\end{array}$ & $\mathrm{F}$ & 57 & $\begin{array}{l}\text { No (gene } \\
\text { assay } \\
\text { verified) }\end{array}$ & M & $\begin{array}{l}\text { Liver: } \\
\text { AML(6cm) }\end{array}$ & $\begin{array}{l}\text { Bilateral lung: } \\
\text { multiple } \\
\text { AML(0.2- } \\
1.0 \mathrm{~cm})(5 \\
\text { years later) }\end{array}$ & $\begin{array}{l}\text { No malignant } \\
\text { phenotype }\end{array}$ & $\begin{array}{l}\text { Surgical } \\
\text { resection }\end{array}$ & $\begin{array}{l}\text { Stable } \\
\text { (followed } \\
\text { up for } 3 \\
\text { years) }\end{array}$ \\
\hline 10 & $\begin{array}{l}\text { Kim, N. } \\
\text { R., et al. } \\
(2003) \\
{[23]}\end{array}$ & M & 47 & $\begin{array}{l}\text { Presumptive } \\
\text { TSC(based } \\
\text { on clinical } \\
\text { presentation) }\end{array}$ & $S$ & $\begin{array}{l}\text { Liver } 囚 \text { multiple } \\
\text { AML }(2-11 \mathrm{~cm})\end{array}$ & $\begin{array}{l}\text { Left kidney: } \\
\text { AML(1cm } \\
\text { ) ; Bilateral } \\
\text { Lung: } \\
\text { multiple LAM }\end{array}$ & $\begin{array}{l}\text { No malignant } \\
\text { phenotype }\end{array}$ & $\begin{array}{l}\text { Surgical } \\
\text { resection }\end{array}$ & $\begin{array}{l}\text { Lost follow } \\
\text { up }\end{array}$ \\
\hline 11 & $\begin{array}{l}\text { Dimmler, } \\
\text { A., et al. } \\
(2003) \\
{[16] .}\end{array}$ & $\mathrm{F}$ & 68 & No mention & M & $\begin{array}{l}\text { Uterine: } \\
\text { PEComa( } \\
4 \mathrm{~cm})\end{array}$ & $\begin{array}{l}\text { Lung: } \\
\text { multiple } \\
\text { PEComa( 0.3- } \\
2.0 \mathrm{~cm})(7 \\
\text { years later) }\end{array}$ & $\begin{array}{l}\text { No malignant } \\
\text { phenotype }\end{array}$ & $\begin{array}{l}\text { Surgical } \\
\text { resection }\end{array}$ & $\begin{array}{l}\text { No } \\
\text { recurrence }\end{array}$ \\
\hline
\end{tabular}




\begin{tabular}{|c|c|c|c|c|c|c|c|c|c|c|}
\hline 12 & $\begin{array}{l}\text { Mai, K. T., } \\
\text { et al. } \\
(2001) \\
{[12]}\end{array}$ & $\mathrm{M}$ & 47 & No mention & M & $\begin{array}{l}\text { Kidney: } \\
\text { epithelioid } \\
\text { AML(15 } \\
\times 12 \mathrm{~cm})\end{array}$ & $\begin{array}{l}\text { Liver: multiple } \\
\text { epithelioid } \\
\text { AML(up to } \\
5 \mathrm{~cm} \text { )(9 } \\
\text { month later) }\end{array}$ & $\begin{array}{l}90 \% \text { of } \\
\text { epithelioid } \\
\text { morphology }\end{array}$ & $\begin{array}{l}\text { Surgical } \\
\text { resection }\end{array}$ & No mention \\
\hline
\end{tabular}

"TSC" represents tuberous sclerosis complex; “M" represents metachronous; "S" represents simultaneous

\section{Figures}

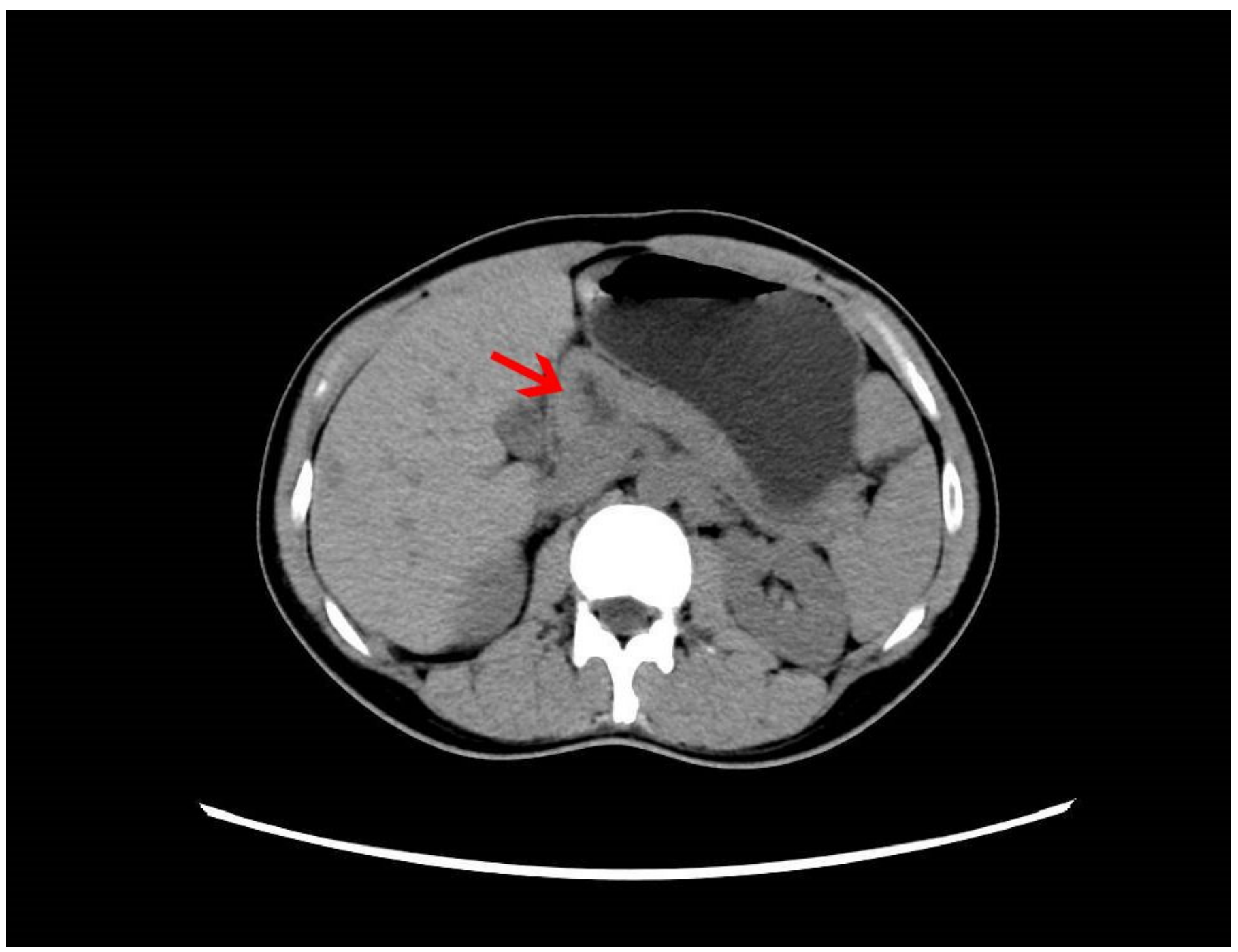

\section{Figure 1}

the lesion in pancreas: CT showed that there was a low-density area in the head of the pancreas, the largest cross-section was about $1.9 \times 1.8 \mathrm{~cm}$, and the lesion was closely related to the head of the pancreas and the proper hepatic artery. 


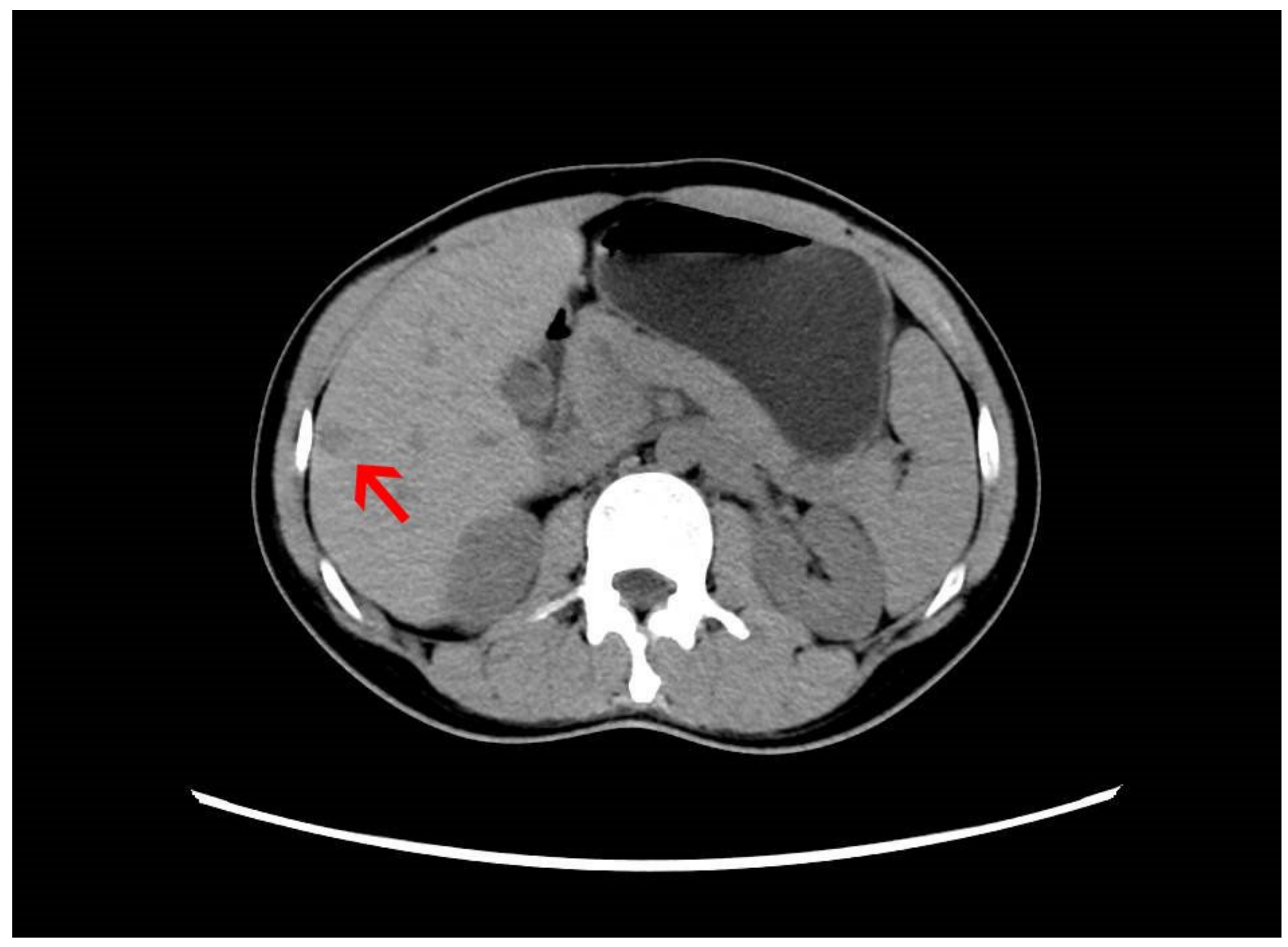

Figure 2

the lesion in liver: There was a low-density area at the segment $5 / 6$ junction of the liver, the size was about $1.1 \times 1.0 \mathrm{~cm}$. 

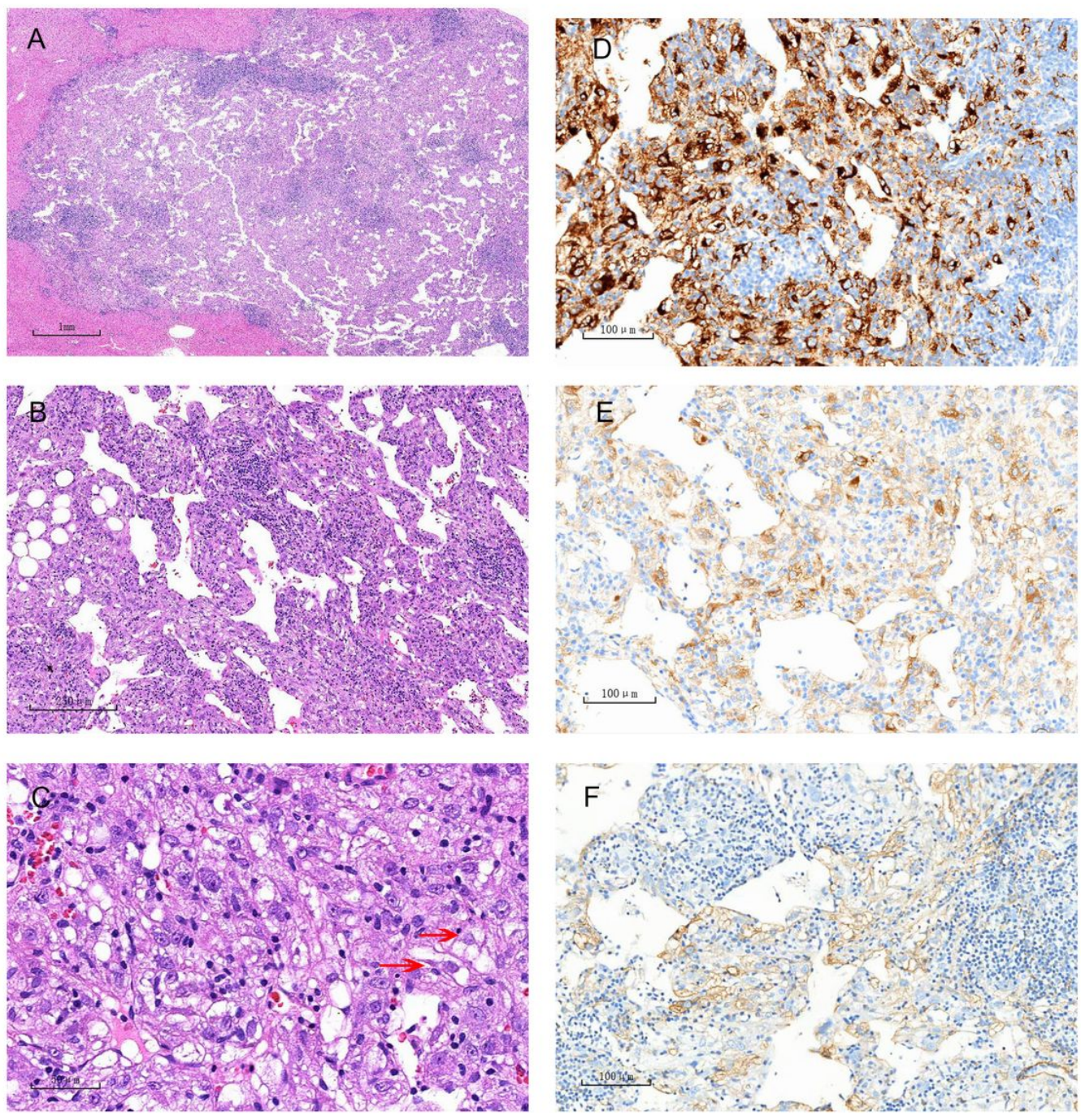

\section{Figure 3}

Histological morphology (H\&E) and immunohistochemical staining of lesion in liver. A A well-defined intrahepatic nodule. B The tumor tissue was rich in blood vessels and had a small amount of adipose tissue. C The tumor was mainly composed of epithelioid cells, among which a small number of short spindle cells and spider web-like cells (shown by arrows) were seen. D HMB45 immunohistochemical staining showed that most of the tumor cells were positively expressed. E MelanA immunohistochemical staining showed positive expression in some tumor cells. F SMA immunohistochemical staining showed weak positive expression in a small number of tumor cells. 

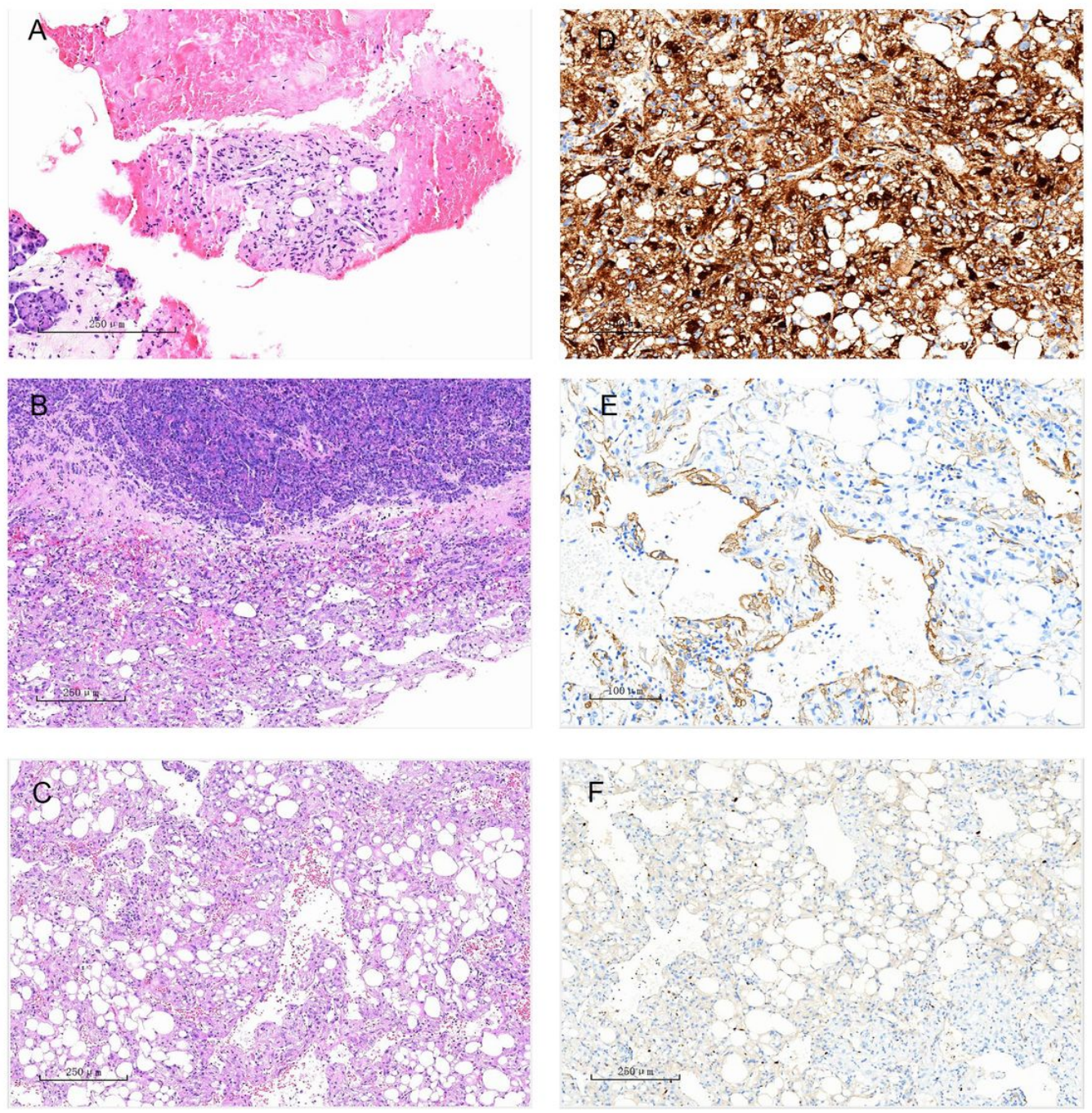

\section{Figure 4}

Histological morphology (H\&E) and immunohistochemical staining of lesion in pancreas. A Intraoperative puncture biopsy of pancreatic tumor. B There was a lesion in the pancreatectomy specimen, the morphology of which was consistent with the tumor in the liver. $\mathrm{C}$ Compared with liver tumors, pancreatic tumor tissue contained more adipose component. D HMB45 immunohistochemical staining showed the same diffuse and strong positive expression. E SMA immunohistochemical staining showed positive in the perivascular area. F Ki67 staining showed a low tumor proliferation index.

\section{Supplementary Files}

This is a list of supplementary files associated with this preprint. Click to download.

- CAREchecklist.pdf 